\title{
Cap-dependent eukaryotic initiation factor-mRNA interactions probed by cross-linking
}

\author{
LISA LINDQVIST, ${ }^{1}$ HIROAKI IMATAKA, $^{2}$ and JERRY PELLETIER ${ }^{1,3}$ \\ ${ }^{1}$ Department of Biochemistry, Faculty of Medicine, McGill University, Montreal, Quebec H3G 1Y6, Canada \\ ${ }^{2}$ RIKEN Genomic Sciences Center, Tsurumi-ku, Yokohama 230-0045, Japan \\ ${ }^{3}$ McGill Cancer Centre, Faculty of Medicine, McGill University, Montreal, Quebec H3G 1Y6, Canada
}

\begin{abstract}
Cap-dependent ribosome recruitment to eukaryotic mRNAs during translation initiation is stimulated by the eukaryotic initiation factor (eIF) $4 \mathrm{~F}$ complex and eIF4B. eIF4F is a heterotrimeric complex composed of three subunits: eIF4E, a 7-methyl guanosine cap binding protein; eIF4A, a DEAD-box RNA helicase; and eIF4G. The interactions of eIF4E, eIF4A, and eIF4B with mRNA have previously been monitored by chemical- and UV-based cross-linking approaches aimed at characterizing the initial protein/mRNA interactions that lead to ribosome recruitment. These studies have led to a model whereby elF4E interacts with the 7-methyl guanosine cap structure in an ATP-independent manner, followed by an ATP-dependent interaction of eIF4A and eIF4B. Herein, we apply a splint-ligation-mediated approach to generate 4-thiouridine-containing mRNA adjacent to a radiolabel group that we utilize to monitor cap-dependent cross-linking of proteins adjacent to, and downstream from, the cap structure. Using this approach, we demonstrate interactions between eIF4G, eIF4H, and eIF3 subunits with the mRNA during the cap recognition process.
\end{abstract}

Keywords: protein-mRNA interactions; eIF4F; eIF4H; eIF3; 4-thiouridine

\section{INTRODUCTION}

Ribosome recruitment to mRNA templates is generally thought to be the rate-limiting step of protein synthesis in eukaryotes (Duncan et al. 1987). This process is controlled by signal transduction mechanisms that impinge on mTOR, which in turn regulates assembly of the eukaryotic initiation factor (eIF) $4 \mathrm{~F}$ complex. eIF4F is composed of three subunits: eIF4E, which binds to the cap structure ( $\mathrm{m}^{7} \mathrm{GpppN}$; where $\mathrm{N}$ is any nucleotide); eIF4A, a DEAD-box RNA helicase involved in preparing a ribosome landing pad for $43 \mathrm{~S}$ pre-initiation complexes (40S ribosomal subunit and associated factors) by unwinding $5^{\prime}$ end mRNA structure; and eIF4G, a large scaffolding protein involved in recruiting the $43 \mathrm{~S}$ pre-initiation complex via its interaction with 40S-associated eIF3 (Pestova et al. 2001). eIF4B and eIF4H are RNA chaperones implicated in the ribosome recruitment phase via their enhancement of eIF4A helicase

Reprint requests to: Jerry Pelletier, Department of Biochemistry, Faculty of Medicine, McIntyre Medical Sciences Building, Room 810, 3655 Promenade Sir William Osler, McGill University, Montreal, Quebec H3G 1Y6, Canada; e-mail: jerry.pelletier@mcgill.ca; fax: (514) 398-7384.

Article published online ahead of print. Article and publication date are at http://www.rnajournal.org/cgi/doi/10.1261/rna.971208. activity, although eIF4H/mRNA interactions during translation initiation have not been reported (Rogers et al. 2001).

Our current understanding of factor assembly on mRNA templates during translation initiation is based on reconstitution and biochemical approaches that have dissected various steps of this process. Of note is the use of crosslinking approaches to monitor the interaction of initiation factors with the cap structure. In a classic chemical-based approach, the cis-diols of the cap ribose moiety and of the 3' most nucleotide are oxidized to aldehydes using sodium periodate (Sonenberg et al. 1978). Following incubation with proteins, Schiff bases formed between the cis-aldehydes and free amino groups on proteins are subsequently reduced with sodium cyanoborohydride (Sonenberg et al. 1978). The presence of a radiolabel in the cap structure enables visualization of cross-linked proteins with specificity assessed by performing parallel incubations in the presence of $\mathrm{m}^{7} \mathrm{GDP}$ (specific competitor) or GDP (nonspecific competitor). This assay is used to track the behavior of eIF4E, eIF4A, and eIF4B with the cap structure and has demonstrated that cap binding of eIF4E is ATP independent, whereas cross-linking of eIF4A and eIF4B is ATP dependent (Sonenberg 1981). In a different approach, $\mathrm{UV}_{254}$-induced 
cross-linking to mRNA cap structures documented the influence of secondary structure on eIF4B binding to mRNA (Pelletier and Sonenberg 1985b).

However, these assays are limited with respect to sampling a restricted number of protein/mRNA interactions at the $5^{\prime}$ cap structure and documenting activity of only eIF4E, eIF4A, and eIF4B. To better understand the ribosome recruitment step, we have generated site-specifically modified mRNA using a photoactivateable group, 4-thiourdine (4SU), which cross-links proteins within one bond length $(\sim 2 \AA)$ upon irradiation with $U_{365}$ (Moore and Query 1998). This approach allowed us to sample capdependent interaction of initiation factors to mRNA adjacent to, and downstream from, the cap structure. We demonstrate that, in addition to detecting eIF4E-, eIF4A-, and eIF4B-mRNA interactions, eIF4G, eIF4H, eIF3a, eIF3c, and eIF3d are found to be in intimate contact with mRNA during the cap recognition process. We also detect capdependent interactions of eIF4B, eIF4H, and eIF3a with mRNA up to 52 nucleotides (nt) downstream from the $5^{\prime}$ end.

\section{RESULTS}

\section{Cap-dependent mRNA-protein interactions revealed by $\mathrm{UV}_{365}$-induced cross-linking}

To enrich our understanding of translation initiation factors that interact with mRNA prior to the ribosome recruitment phase of translation initiation, we generated an
mRNA template in which we engineered $4 \mathrm{SU}$ at specific positions downstream from the cap structure (see Materials and Methods). Proteins can then be cross-linked to 4SU sites upon irradiation with $\mathrm{UV}_{365}$ (Moore and Query 1998). Since cap recognition is important for a number of cellular processes, such as splicing (Konarska et al. 1984; Edery and Sonenberg 1985), and we wished to focus only on capdependent events associated with translation initiation, we utilized initiation factor preparations prepared from highsalt washed ribosomes (RSW) in our studies. We first compared the eIF-mRNA cross-linking profiles obtained by the chemical (Fig. 1A; Sonenberg 1981), $\mathrm{UV}_{254}$-induced (Fig. 1B; Pelletier and Sonenberg 1985b), and $\mathrm{UV}_{365^{-}}$ induced approach (Fig. 1C). The latter used an mRNA harboring a $4 \mathrm{SU}$ group positioned at the +2 position $\left(4 \mathrm{SU}^{2}\right)$ downstream from the radiolabeled cap structure, generated by in vitro transcription of a template that enabled incorporation of a single $4 \mathrm{SU}$ at this position (see Materials and Methods). Cap specificity was assessed by performing parallel incubations in the presence of the cap analog, $\mathrm{m}^{7} \mathrm{GDP}$. Using the chemical cross-linking approach, the cap-dependent binding of eIF4E, eIF4A, and eIF4B was apparent (Fig. 1A, cf, lanes 1,3 and 2). $\mathrm{UV}_{254}$-induced cross-linking detected the cap-specific binding of eIF4B (Fig. 1B, cf. lanes 3,1 and 2). As previously reported, cross-linking of eIF4B is ATP dependent (Fig. 1B, cf. lanes 4 and 1) and is the most prominent initiation factor detected by the $\mathrm{UV}_{254}$-based assay (Pelletier and Sonenberg 1985b).
A

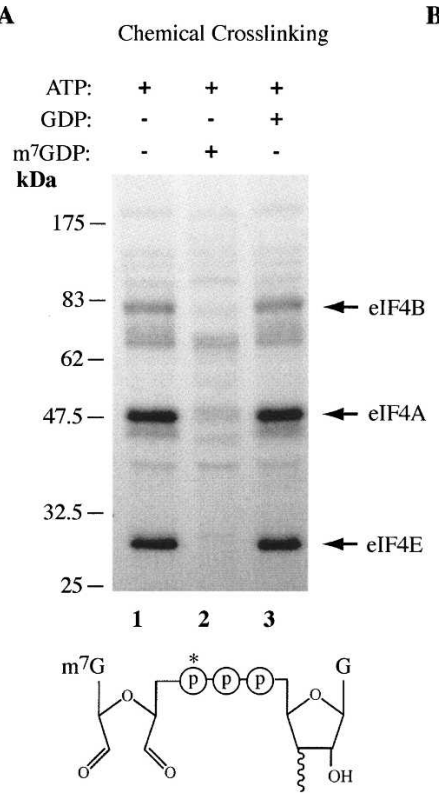

B

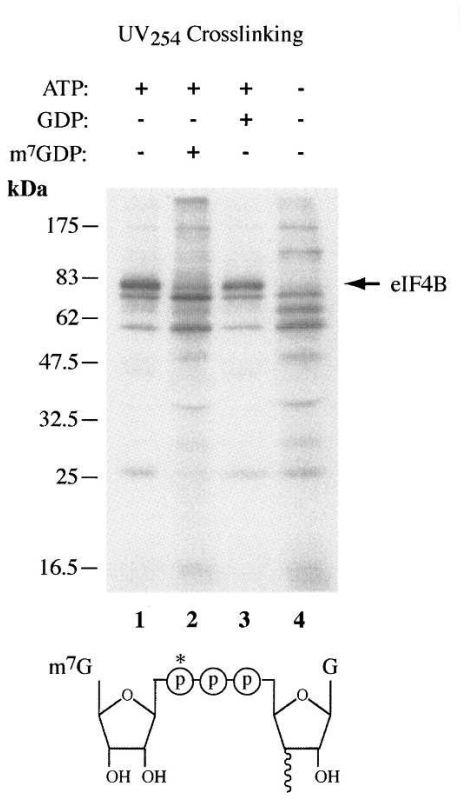

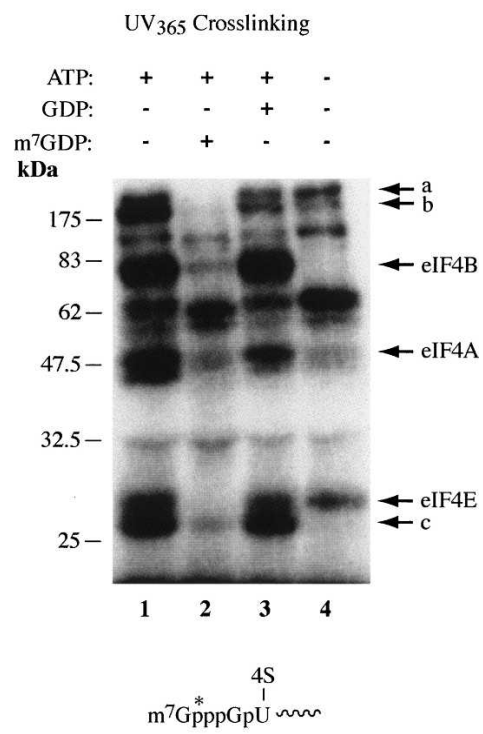

FIGURE 1. Comparative profiling of cap-dependent cross-linking with RSW using chemical- and UV-induced approaches. RSW was incubated with ${ }^{32} \mathrm{P}$-cap-labeled mRNA followed by $(A)$ chemical, $(B) \mathrm{UV}_{254}$-induced, and $(C) \mathrm{UV}_{365}$-induced cross-linking. The presence of ATP, $\mathrm{m}^{7} \mathrm{GDP}$, or GDP in the cross-linking reactions is indicated at the top of each panel. A schematic diagram indicating the relative positions of the cap, the radiolabel (asterisks), and the 4SU group is shown below each panel. 
$\mathrm{UV}_{365}$-induced cross-linking revealed a more complex set of cap-specific binding proteins (Fig. 1C). A set of proteins that showed molecular masses and cross-linking behavior consistent with their identity being eIF4E, eIF4A, and eIF4B was detected (Fig. 1C, cf. lanes 3,1 and 2). (We confirm the identity of these proteins below.) In addition, we observed the cap-dependent cross-linking of three new polypeptides (Fig. 1C, labeled a,b,c). The cross-linking of eIF4A, eIF4B, and polypeptides b and $\mathrm{c}$ was ATP dependent (Fig. 1C, cf. lanes 4 and 1). The cross-linking of eIF4E and polypeptide a was not ATP dependent (Fig. 1C, cf. lanes 4 and 1). No proteins were cross-linked in the absence of $\mathrm{UV}_{365}$ irradiation or in the absence of a $4 \mathrm{SU}$ group in the mRNA template (data not shown).

\section{Internal cap-dependent mRNA-protein interactions}

We investigated the possibility of using the $4 \mathrm{SU}$-based $\mathrm{UV}_{365}$ cross-linking approach to probe for cap-dependent mRNA-protein interactions occurring downstream from the cap structure. For this approach, we positioned a $4 \mathrm{SU}$ group $12 \mathrm{nt}\left(4 \mathrm{SU}^{12}\right)$ downstream from the cap structure using a splint-directed ligation approach (Moore and Query 1998). $\mathrm{UV}_{365}$-induced cross-linking of methylated, capped $4 \mathrm{SU}^{12}$ pre-incubated with RSW revealed the capdependent cross-linking of five polypeptides (Fig. 2, lanes 1-4) having behaviors consistent with their identities being polypeptides a-c (Fig. 1C), eIF4A, and eIF4B (Fig. 2, cf. lanes 1-4 and Fig. 1C). None of these polypeptides were cross-linked to $4 \mathrm{SU}^{12} \mathrm{mRNA}$ containing an unmethylated
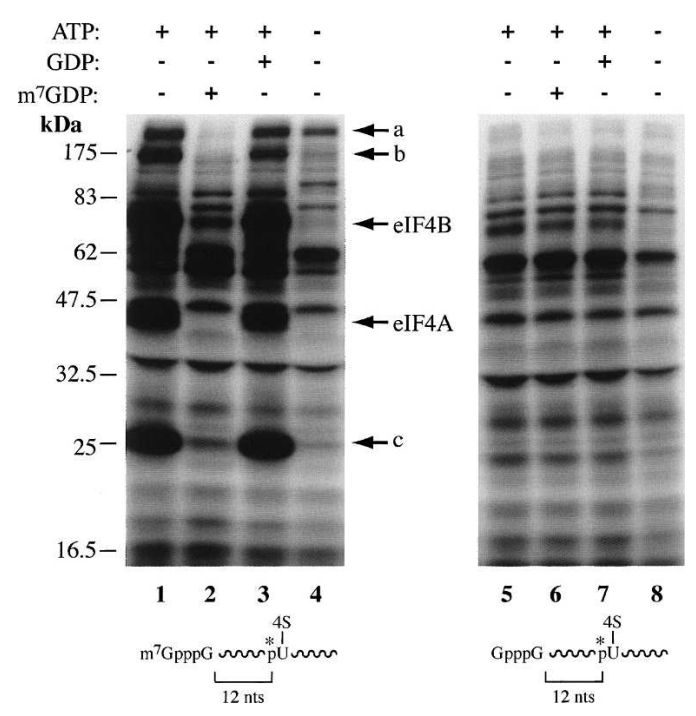

FIGURE 2. Cap-dependent mRNA-protein interactions detected $12 \mathrm{nt}$ downstream from the cap structure by $\mathrm{UV}_{365}$-induced crosslinking. $\mathrm{UV}_{365}$-induced cross-linking of proteins from RSW using $\mathrm{m}^{7}$ GpppG-capped (lanes 1-4) or GpppG-capped (lanes 5-8) 4SU ${ }^{12} \mathrm{RNA}$. A schematic diagram indicating the position of the radiolabel (asterisks), the position of the 4SU residue, and the nature of the cap structure on the mRNA template is indicated below each panel. cap structure (Fig. 2, cf. lanes 5-8 and 1). Of note is the conspicuous absence of eIF4E cross-linked to $4 \mathrm{SU}^{12}$ mRNA.

\section{Identification of $\mathrm{UV}_{365}$-induced cross-linked proteins}

The molecular mass of the $\sim 27-\mathrm{kDa}$ cap-specific protein (polypeptide c) (Figs. 1C, 2), as well as its requirement for ATP in the cross-linking assay, suggested that it might be eIF4H (predicted molecular mass is $27.4 \mathrm{kDa}$ ). To investigate further, we produced antibodies to eIF4H and used the serum in immunoprecipitations (IPs) following crosslinking of RSW to $4 \mathrm{SU}^{2}$ RNA. A single protein was detected in IPs from cross-linking reactions (Fig. 3A, lanes 1,3) that had a similar molecular mass as polypeptide $c$ and was absent from cross-linking reactions performed in the presence of $\mathrm{m}^{7} \mathrm{GDP}$ (Fig. 3A, lane 2) or lacking ATP (Fig. $3 A$, lane 4). Pre-immune serum did not immunoprecipitate this protein (Fig. 3A, cf. lanes 5-8 and 1). Addition of excess unlabeled eIF4H to cross-linked material before performing the IPs demonstrated that eIF4H could specifically compete with the radiolabeled material for the antibody-an effect that was not observed with eIF4A (Fig. 3B, cf. lanes 3 and 4). No cross-linked protein was immunoprecipitated using pre-immune serum (Fig. 3B, cf. lanes 2 and 1). These results indicate that the $\sim 27-\mathrm{kDa}$ protein species detected in the $\mathrm{UV}_{365}$-induced cross-linking assay corresponds to eIF4H (Figs. 1C, 2, polypeptide c). eIF4H showed the same crosslinking behavior when IPs were performed from crosslinked $4 \mathrm{SU}^{12}$ mRNA (data not shown).

IPs with $\alpha$-eIF4E, $\alpha$-eIF4B, and $\alpha$-eIF4GI antisera demonstrated that these factors were cross-linked in a cap-specific manner by the $\mathrm{UV}_{365}$-induced approach (Fig. 3C, lanes 18). eIF4B and eIF4GI were precipitated from cross-linking reactions performed with $4 \mathrm{SU}^{12} \mathrm{mRNA}$ (Fig. 3C). Crosslinking of eIF4GI was not ATP dependent and likely corresponds to polypeptide a observed in Figure 1C and Figure 2 (Fig. 3C, cf. lanes 1-4). As expected, cross-linking of eIF4B was cap and ATP dependent (Fig. 3C, cf. lanes 1-4). eIF4E was precipitated only from cross-linking reactions performed with $4 \mathrm{SU}^{2} \mathrm{mRNA}$ and was not present in IPs performed with $4 \mathrm{SU}^{12} \mathrm{mRNA}$ (Fig. 3C; data not shown). Since we had no antibodies that efficiently precipitated eIF4A, we performed $\mathrm{UV}_{365}$-induced cross-linking assays with RSW supplemented with recombinant eIF4AI-GST (Fig. 3D). Following nuclease treatment, the cross-linking reactions were passed over glutathionine- or $\mathrm{Ni}^{+2}$ affinity resins, and the retained material eluted with Laemmli buffer and analyzed by SDS-PAGE. The results indicate that eIF4AIGST can cross-link internally in a cap-dependent manner.

The $175-\mathrm{kDa}$ cross-linked polypeptide obtained with $4 \mathrm{SU}^{2}$ and $4 \mathrm{SU}^{12}$ RNA (Figs. 1C, 2, polypeptide b) had a molecular mass reminiscent of eIF3a (166.5 kDa, which migrates at $170 \mathrm{kDa}$ ) (Browning et al. 2001; Pestova et al. 2007). Therefore, we immunoprecipitated cross-linking reactions performed with $4 \mathrm{SU}^{2}$ mRNA using an $\alpha$-eIF3a 
A

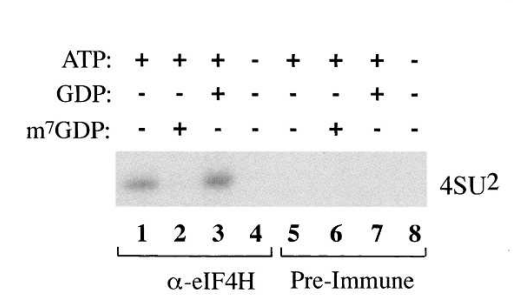

B

$\mathbf{C}$

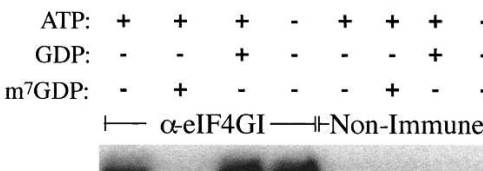

$4 \mathrm{SU} 12$

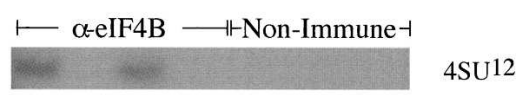

$\longmapsto \alpha$-eIF4E $\longrightarrow$ Non-Immune -

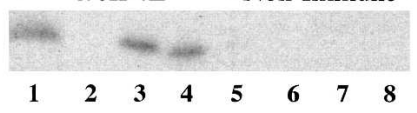

$4 \mathrm{SU} 2$

D

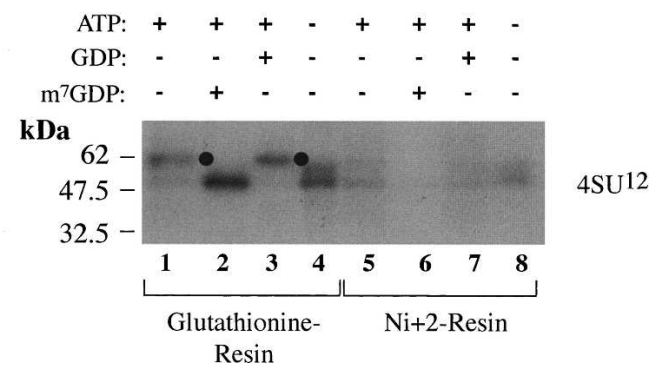

FIGURE 3. Identification of $\mathrm{UV}_{365}$-induced cap-dependent crosslinked proteins. (A) eIF4H is specifically cross-linked near the cap structure in an ATP-dependent fashion. Cross-linking reactions performed using $4 \mathrm{SU}^{2}$ mRNA and RSW were used in IPs with $\alpha$-eIF4H (lanes 14) or pre-immune serum (lanes 5-8). The presence of ATP, $m^{7}$ GDP, or GDP in the cross-linking reactions is indicated above the panel. $(B)$ Specificity of IPs of cross-linked eIF4H by $\alpha$-eIF4H. UV 365 -induced cross-linking reactions to $4 \mathrm{SU}^{2} \mathrm{RNA}$ was used directly in IP reactions (lanes 1,2) or combined with $10 \mu \mathrm{g}$ of $\mathrm{His}_{6}-\mathrm{eIF} 4 \mathrm{H}$ (lane 3) or $\mathrm{His}_{6}-$ eIF4AI (lane 4) prior to IPs. (C) eIF4E, eIF4B, and eIF4GI are crosslinked by the $\mathrm{UV}_{365}$-induced approach. Cross-linking reactions were performed with RSW and $4 \mathrm{SU}^{12}$ or $4 \mathrm{SU}^{2} \mathrm{RNA}$ and used in IPs with $\alpha$-eIF4GI (top panel), $\alpha$-eIF4B (middle panel), and $\alpha$-eIF4E (bottom panel). Immune (lanes 1-4) or nonimmune serum (lanes 5-8) was used. $(D)$ Affinity pulldown of cross-linking reactions performed with RSW supplemented with eIF4AI-GST and $4 \mathrm{SU}^{12}$ RNA. Purifications were performed on glutathione- (lanes 1-4) or $\mathrm{Ni}^{+2}$ (lanes 5-8) resin. The position of migration of eIF4AI-GST recombinant protein is indicated by filled circles.

antibody (Fig. 4A). In addition to eIF3a, three other capspecific cross-linked proteins coimmunoprecipitated (Fig. $4 \mathrm{~A}$, cf. lanes 1,3 and 2). Cross-linking of eIF3a and p47 was ATP dependent, whereas cross-linking of p110 and p66 was ATP independent (Fig. 4A, cf. lanes 4 and 1). None of these polypeptides were observed in parallel reactions performed with nonimmune serum (Fig. 4A, lanes 5-8). A similar pattern of cross-linked proteins was identified when
$\alpha$-eIF3c antibodies were used in IP reactions (eIF3c is 105.3 $\mathrm{kDa}$, but migrates at $100 \mathrm{kDa}$ ) (Fig. 4B; Browning et al. 2001; Pestova et al. 2007). The 66-kDa polypeptide was identified as eIF3d (eIF3d is $64.1 \mathrm{kDa}$ but migrates at 66 $\mathrm{kDa}$ ) (Browning et al. 2001; Pestova et al. 2007), since it could be pulled down by $\alpha$-eIF3d antibodies, but not by $\alpha$-eIF3g antibodies (Fig. 4C, cf. lanes 5-8 and 1-4). The eIF3g antibody was functional as it was able to immunoprecipitate recombinant eIF3g from RSW under the same conditions (data not shown). These experiments indicate that eIF3 subunits are in intimate contact with mRNA following cap recognition by eIF4E, with the interactions of eIF3c and eIF3d being ATP independent. The cross-linking of these polypeptides likely escaped detection without immunoprecipitation due to the presence of co-migrating polypeptides on SDS-polyacrylamide gels that nonspecifically crosslinked to the radiolabeled mRNA template (Figs. 1C, 2). We do not know the identity of the p47 polypeptide although it likely corresponds to one of the eIF3 subunits.

\section{Dependency of initiation factor binding to mRNA on prior interaction of eIF4A with RNA}

We next utilized hippuristanol, a selective inhibitor of eIF4A RNA binding (Bordeleau et al. 2006b) to determine which eIF-mRNA interaction was dependent on prior interaction of eIF4A with RNA. When cross-linking reactions were performed with RSW to $4 \mathrm{SU}^{12} \mathrm{RNA}$ in the presence of hippuristanol, binding of eIF4H, eIF4A, and eIF4B was curtailed (Fig. 5A, cf. lanes 5 and 1-4). Similar results were observed when using $4 \mathrm{SU}^{2}$ as the mRNA template (data not shown). This was not a consequence of hippuristanol directly inhibiting the RNA binding properties of eIF4B (Bordeleau et al. 2006b) or eIF4H (data not shown). We found that AMP-P $\left(\mathrm{CH}_{2}\right) \mathrm{P}$ also inhibited the crosslinking of eIF4B and eIF4H in the $\mathrm{UV}_{365}$-induced assay (data not shown), indicating that ATP hydrolysis by eIF4A, and not merely ATP binding, is required. Cross-linking of eIF4G was ATP independent (Fig. 5A, cf. lanes 4 and 1,3) and independent of the binding of eIF4A to RNA (Fig. 5A, cf. lanes 5 and 4 ).

Cross-linking experiments were also performed in the presence of hippuristanol with $4 \mathrm{SU}^{2}$ and immunoprecipitated with $\alpha$-eIF3c antibodies (Fig. 5B). eIF3c and eIF3d were found to cross-link in a cap-dependent manner in the presence of hippuristanol, whereas cross-linked eIF3a and p47 were not detected (Fig. 5B). Like eIF4G (Fig. 5A), eIF3c and eIF3d bind mRNA in an ATP-independent manner and are not dependent on prior binding of eIF4A to RNA.

\section{Internal positioning of translation factors detected by cross-linking}

Cross-linking of eIF4E is observed with $4 \mathrm{SU}^{2}$ mRNA (Fig. 1C) but is not detected when reactions are performed with $4 \mathrm{SU}^{12}$ RNA (Fig. 2). We therefore wished to assess if the 
A

B
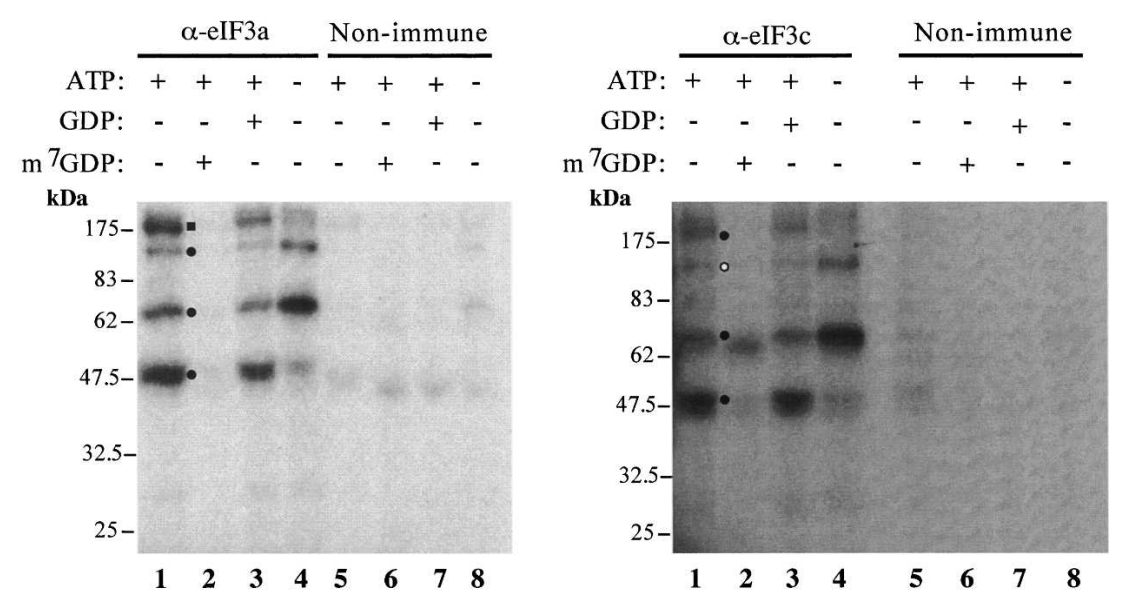

C

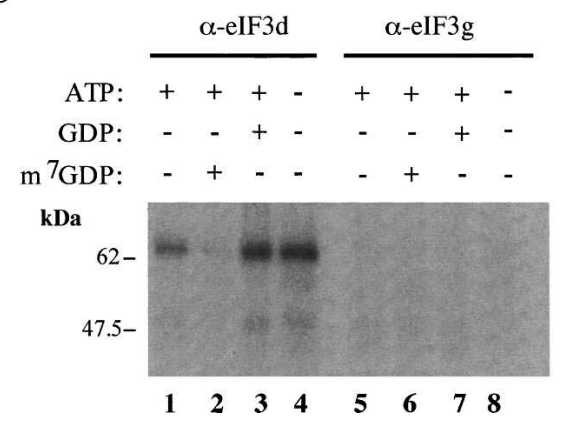

FIGURE 4. Cap-specific cross-linking of eIF3 subunits. (A) $\mathrm{UV}_{365}$-induced cross-linking reactions with $4 \mathrm{SU}^{2}$ were used in IPs with $\alpha$-eIF3a antibodies. The position of migration of eIF3a is denoted by a blackened box, whereas the presence of coprecipitating proteins is denoted by filled circles. $(B)$ IPs of cross-linking reactions performed with $\alpha$-eIF3c antisera. The position of migration of eIF3c is denoted by an open circle and the presence of coprecipitating proteins is denoted by filled circles. (C) IPs of cross-linking reactions with $\alpha$-eIF3d and $\alpha$-eIF3g antiserum.

nature of the mRNA-protein interactions would change as a function of increased distance between the $4 \mathrm{SU}$ group and the cap structure. Three RNA substrates were generated in which $4 \mathrm{SU}$ was positioned 12, 22, or $52 \mathrm{nt}$ from the cap structure (Fig. 6). Of notable absence is eIF4E in any of the cross-linking reactions. We observed the presence of eIF4H, eIF4A, eIF3a, and eIF4G on 4SU ${ }^{12}$ RNA (Fig. 6, cf. lanes 4,2 and 3,1). The cross-linking efficiency of eIF4H, eIF4A, eIF4B, and eIF4G diminished as a consequence of increasing the distance of the $4 \mathrm{SU}$ group from the cap structure, whereas the cross-linking of eIF3a did not appear to change (Fig. 6, cf. lanes 9-12 and 5-8,1-4). These results indicate cap-dependent remodeling of the mRNA by eIFs within the 5' UTR following cap recognition.

\section{DISCUSSION}

Herein, we have used a site-directed cross-linking approach to monitor the cap-dependent interaction of translation initiation factors at various positions downstream from the cap structure. In these assays, we utilized crude initiation factor preparations to specifically focus on events prior to the ribosome binding step. We find that, whereas eIF4E can be cross-linked 2 nt from the cap structure, it is not detected 12 nt downstream from the cap structure (Figs. 1, 2). This is unlikely due to the small molecular mass of eIF4E, since eIF4H has a comparable molecular mass, and cross-linking of this protein is observed up to $52 \mathrm{nt}$ downstream from the cap structure (Figs. 1, 6).

Cap-dependent cross-linking of mammalian eIF4GI is also clearly demonstrated by our approach and, like eIF4E, its binding to mRNA is not dependent on ATP-hydrolysis or eIF4ARNA interaction (Figs. 3C, 5A). This is consistent with eIF4GI (and eIF4GII) having RNA binding domains, previously shown to interact with the EMCV (for eIF4GI) and FMDV (for eIF4GI and eIF4GII) IRESes in an ATPindependent manner (Pestova et al. 1996; Kolupaeva et al. 1998; Pilipenko et al. 2000; Lopez de Quinto et al. 2001). Although we have not formally demonstrated cross-linking of eIF4GII to the cap structure in the $4 \mathrm{SU}$-based $\mathrm{UV}_{365}$-induced cross-linking assay, we expect a behavior similar to eIF4GI, given that the proteins are functionally similar (Gradi et al. 1998). The binding of eIF4G to RNA may help stabilize the initial eIF4E $/ \mathrm{m}^{7} \mathrm{G}$ cap interaction as well as stimulate RNA binding to eIF4A (Oberer et al. 2005), thus firmly positioning eIF4F at the $5^{\prime}$ end of the mRNA. It is difficult to detect cross-linking of eIF4GI to mRNA when the 4SU group is located beyond $12 \mathrm{nt}$ downstream from the cap structure (Fig. 6). One interpretation of this result is that eIF4GI remains stationary at the $5^{\prime}$ cap structure with eIF4E.

eIF4A is delivered to the mRNA as a subunit of the eIF4F complex where it is thought to unwind local secondary structure and prepare a ribosome landing pad on the mRNA template. However, it is unclear how eIF4A achieves this. One model is that eIF4A hydrolyzes ATP to disrupt base-pairing within the $5^{\prime}$ UTR and moves along the $5^{\prime}$ UTR, with single stranded regions generated by this process captured by eIF4B and/or eIF4H (for review, see Kapp and Lorsch 2004). Another hypothesis is that multiple eIF4A molecules seed the mRNA 5' UTR with eIF4F being the nucleation event (Sonenberg 1988; Kapp and Lorsch 2004). 
$\mathbf{A}$

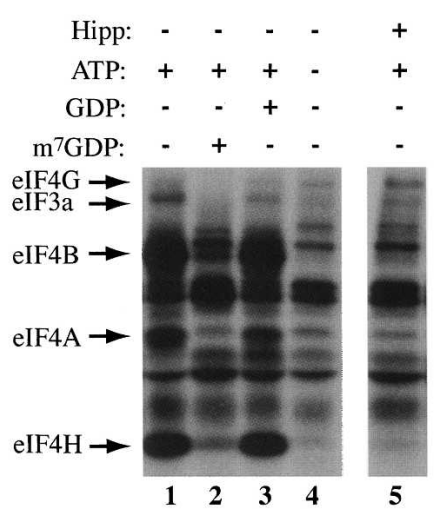

B

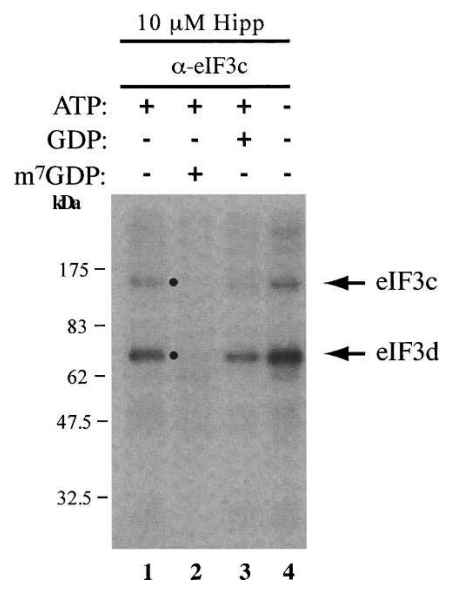

FIGURE 5. eIF4A-RNA dependency of initiation factor cross-linking. (A) $\mathrm{UV}_{365}$-induced cross-linking of RSW to $4 \mathrm{SU}^{12}$ RNA was performed in the absence (lanes 1-4) or presence (lane 5) of $10 \mu \mathrm{M}$ hippuristanol. The position of migration of known initiation factors is denoted. The cross-linking reaction in lane 5 was analyzed on the same SDS-polyacrylamide gel as those of lanes 1-4, but not adjacent to these reactions. (Note that the cross-linking of eIF4G in lane 1 in this experiment is not as apparent as it is in other experiments [e.g., Fig. 2] and this may be factor preparation dependent.) (B) Crosslinking reactions were performed using $4 \mathrm{SU}^{2}$ RNA and RSW in the presence of $10 \mu \mathrm{M}$ hippuristanol and immunoprecipitated using $\alpha$-eIF3c antibodies. The presence of ATP, $\mathrm{m}^{7} \mathrm{GDP}$, or GDP in the cross-linking reactions is indicated.

Our results do not address whether multiple molecules of eIF4A are deposited on the mRNA per eIF4F binding event since diminished cross-linking downstream from the cap structure need not imply a lack of eIF4A molecules (Pause et al. 1994; Kapp and Lorsch 2004). However, we did observe robust internal cross-linking of eIF4H and eIF4B at positions 2, 12, 22, and $52 \mathrm{nt}$ downstream from the cap structure, albeit at reduced efficiency when the position of the $4 \mathrm{SU}$ group moved further from the cap structure (Figs. $1,2,6)$. This does not appear to be a nonspecific reduction in overall efficiency, since the cross-linking of eIF3a was not affected (Fig. 6). We propose that these results are consistent with a model where multiple eIF4B and eIF4H (and eIF4A) molecules seed the mRNA to produce a stable ribonucleoprotein complex (Fig. 7). eIF4B and eIF4H may behave as RNA chaperones and remodel RNA in the absence of ATP hydrolysis (Cristofari and Darlix 2002). The eIF4A dependency of this step could reflect the need for eIF4A to prepare the mRNA template and allow initial "seeding" of the mRNA template by eIF4B/H (Fig. 7; Cristofari and Darlix 2002).

Mammalian eIF3 contains 11 subunits, of which eIF3a (p170), eIF3b (p116), eIF3c (p100), eIF3d (p66), eIF3f (p47), and eIF3g (p44) are capable of binding to RNA (Nygård and Westermann 1982; Asano et al. 1997; Block et al. 1998; Buratti et al. 1998; Sizova et al. 1998). We find that RNA binding of eIF3b and eIF3d is neither ATP nor eIF4A dependent (Fig. 4). These results indicate that some eIF3 subunits are in intimate contact with the mRNA 5' UTR downstream from the cap structure. This event is likely eIF4G dependent since the central domain of eIF4G interacts with eIF3 (Imataka and Sonenberg 1997), through the eIF3e subunit (LeFebvre et al. 2006). Although our experiments were performed with initiation factor preparations lacking $40 \mathrm{~S}$ or $60 \mathrm{~S}$ ribosomal subunits, cryo-EM reconstitutions of eIF4G, eIF3, and $40 \mathrm{~S}$ ribosomes indicate that eIF3 is adjacent to eIF4F and RNA—consistent with an eIF4F-dependent interaction of eIF3 with mRNA (Siridechadilok et al. 2005). The functional significance of the eIF3-mRNA interactions needs to be better characterized but may be related to stabilization of the initial eIF4FmRNA interaction and/or subsequent eIF4B-mRNA and eIF4H-mRNA interactions (Fig. 7). Neither of these possibilities is mutually exclusive. eIF4B associates with eIF3 and

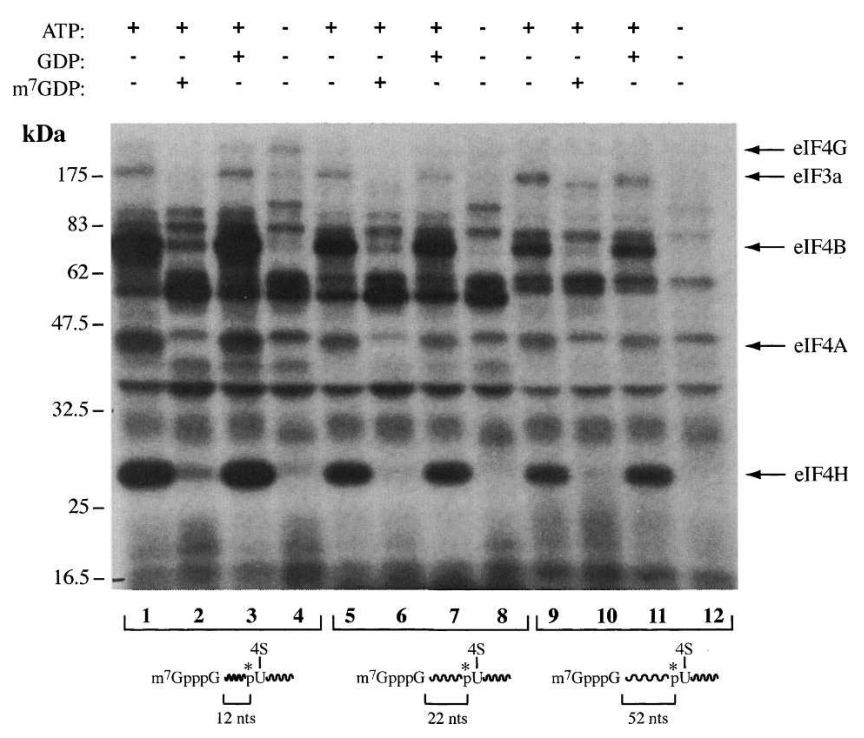

FIGURE 6. Cap-dependent cross-linking of initiation factors as a function of $4 \mathrm{SU}$ position. $\mathrm{UV}_{365}$-induced cross-linking of proteins from RSW using $4 \mathrm{SU}^{12}$ (lanes 1-4), 4SU $\mathrm{SL}^{22}$ (lanes 5-8), or $4 \mathrm{SU}^{52}$ (lanes 9-12) RNA. The identity of translation initiation factors is indicated to the right. 


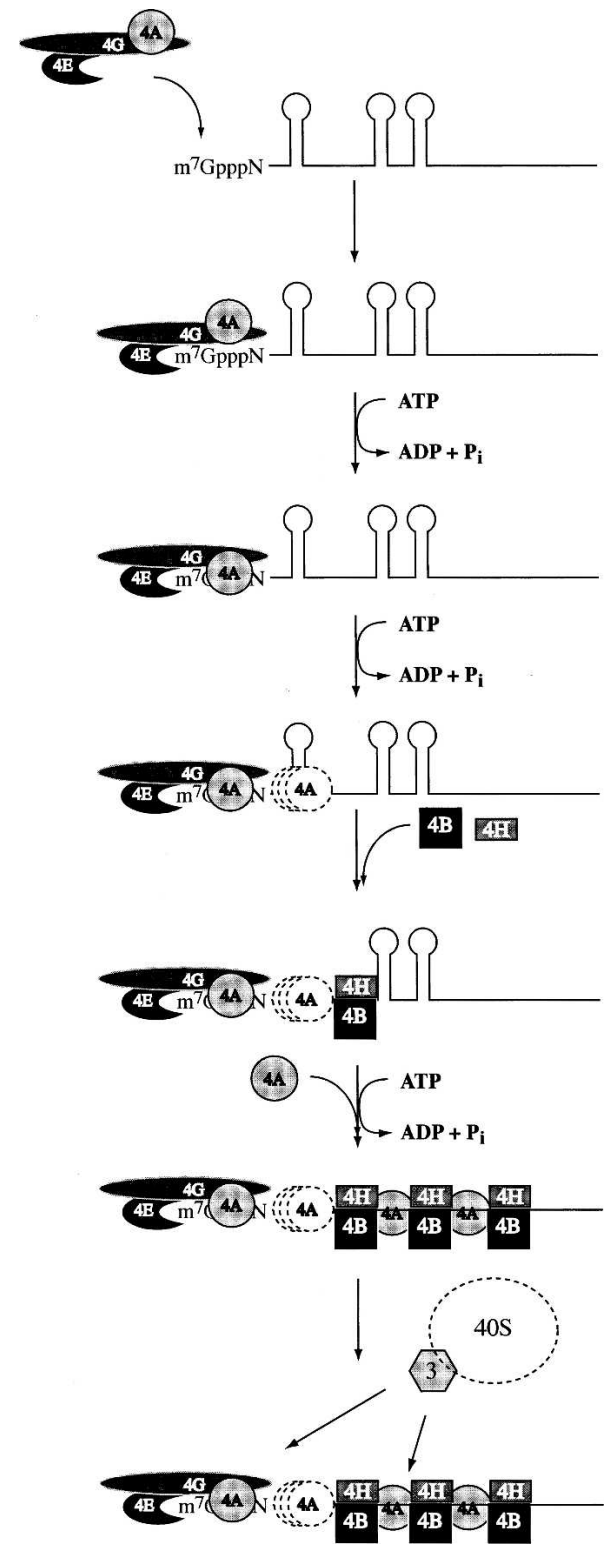

FIGURE 7. Schematic diagram illustrating a model of action of mRNA binding proteins in translation initiation. The first step is the ATP-independent binding of eIF4E, which is likely stabilized by binding of eIF4G to mRNA. The next step is hydrolysis of ATP by eIF4A and remodeling of the mRNA template that facilitates eIF4B and eIF4H binding. Binding of eIF4B and eIF4H on the mRNA is ATP and eIF4A dependent. The interaction of eIF3 with eIF4F and eIF4B/H is not mutually exclusive. Our results do not exclude the possibility that eIF3 and eIF4F form functional complexes in solution, independent of the $40 \mathrm{~S}$ ribosome prior to eIF4F-RNA interaction.

this is postulated to bridge the mRNA/ribosome interaction (Methot et al. 1996; Vornlocher et al. 1999). The interaction of eIF3a with RNA is not restricted to the cap structure and may indicate internal recruitment of eIF3 by eIF4B/H (which would nonetheless be cap dependent) (Fig. 7).

Secondary structure at the cap structure, as well as within the $5^{\prime}$ UTR, is inhibitory to translation (Pelletier and
Sonenberg 1985a; Parkin et al. 1988; Svitkin et al. 2001), yet these may function in very different ways to inhibit translation (Lawson et al. 1988). Our model rationalizes two consequences of secondary structure within the mRNA 5' UTR. On one hand, cap-proximal secondary structure could impair eIF4A activity to decrease the efficiency of cap recognition by eIF4E (Svitkin et al. 2001). As well, downstream secondary structure could affect eIF4B/H seeding rates and may explain the requirement on eIF4B for initiation on transcripts that have even moderate base-pairing within their 5' UTRs (Dmitriev et al. 2003). eIF4B activity may be regulated by phosphorylation by mTOR and MAPK pathways (Shahbazian et al. 2006), an event that is also associated with recruitment of eIF4B into eIF3-containing pre-initiation complexes (Holz et al. 2005). It remains to be established if altered eIF4B/H binding rates on mRNAs with differing secondary structure affect the competitive nature of these mRNAs.

\section{MATERIALS AND METHODS}

\section{Preparation of ribosomal salt wash}

Ribosomal high salt washes (RSW) were prepared as previously described (Lorsch and Herschlag 1999). Briefly, rabbit reticulocyte lysate $(25 \mathrm{~mL})$ was centrifuged at $100,000 \mathrm{~g}$ for $2 \mathrm{~h}$ in a Ti50 rotor. The ribosomal pellet was resuspended in $0.5 \mathrm{~mL}$ of Buffer A (30 $\mathrm{mM} \mathrm{HEPES}_{7.5}, 100 \mathrm{mM} \mathrm{KOAc,} 2 \mathrm{mM} \mathrm{Mg}[\mathrm{OAc}]_{2}, 0.1 \mathrm{mM}$ EDTA, $2 \mathrm{mM}$ DTT, $0.4 \mathrm{M} \mathrm{KCl}, 0.25 \mathrm{M}$ sucrose, $1 \mathrm{mM}$ PMSF, $2 \mu \mathrm{g} / \mathrm{mL}$ leupeptine, $1 \mu \mathrm{g} / \mathrm{mL}$ pepstatin $\mathrm{A}, 2 \mu \mathrm{g} / \mathrm{mL}$ aprotinin) using a stirring bar on ice for 1-2 $\mathrm{h}$. The suspension was layered on top of a 3-mL sucrose cushion (Buffer A + $1 \mathrm{M}$ sucrose) and centrifuged for $3.5 \mathrm{~h}$ in a Ti50 rotor at 100,000g. The supernatant was dialyzed against $20 \mathrm{mM}$ Tris $_{7.5}, 1 \mathrm{mM}$ DTT, $0.1 \mathrm{mM}$ EDTA, $150 \mathrm{mM} \mathrm{KCl}$, $10 \%$ glycerol and stored at $-80^{\circ} \mathrm{C}$.

\section{Purification of recombinant proteins}

The expression vector, pET15b-eIF4AI, contains the eIF4AI coding region inserted into the NdeI/BamH I sites of pET15b. pET28a/eIF4H was obtained by PCR amplification of the murine eIF4H coding region, followed by insertion into the NdeI/BamH I sites of pET28a. Recombinant $\mathrm{His}_{6}$-eIF4AI and $\mathrm{His}_{6}$-eIF4H were expressed in Escherichia coli BL21 (DE3) codon+ cells. Bacteria were grown to an $\mathrm{OD}_{600}$ of 0.6 and induced with $1 \mathrm{mM}$ IPTG after which growth was continued an additional $3 \mathrm{~h}$ at $37^{\circ} \mathrm{C}$. Bacteria were resuspended in sonication buffer $\left(20 \mathrm{mM} \mathrm{Tris}_{7.5}, 10 \%\right.$ glycerol, $0.1 \mathrm{mM}$ EDTA, $200 \mathrm{mM} \mathrm{KCl}, 0.1 \%$ Triton X-100, and $3.4 \mathrm{mM} \beta$-mercaptoethanol), sonicated (nine pulses of $20 \mathrm{sec}$ ), clarified by centrifugation $(2 \times$ at $27,000 \mathrm{~g}$ for $30 \mathrm{~min}$ each), and the lysate loaded on a $\mathrm{Ni}^{++}$-NTA agarose (Qiagen) column. After washing with wash 1 buffer $\left(20 \mathrm{mM}\right.$ Tris ${ }_{7.5}, 10 \%$ glycerol, $0.1 \mathrm{mM}$ EDTA, $800 \mathrm{mM} \mathrm{KCl}, 20 \mathrm{mM}$ imidazole) and wash 2 buffer (wash 1 containing $300 \mathrm{mM} \mathrm{KCl}$ ), the $\mathrm{His}_{6}$-tagged proteins were eluted with elution buffer (wash 1 containing $100 \mathrm{mM} \mathrm{KCl}$ and $0.2 \mathrm{M}$ imidazole) and dialyzed into A100 buffer (20 mM Tris $\mathrm{m}_{7.5}, 10 \%$ glycerol, $0.1 \mathrm{mM}$ EDTA, $100 \mathrm{mM} \mathrm{KCl}, 2 \mathrm{mM}$ DTT). The $\mathrm{His}_{6}{ }^{-}$ eIF4AI was then loaded onto a Q-Sepharose Fast Flow (Amersham) 
column and eluted with a salt gradient A100 to A500 (A100 containing $500 \mathrm{mM} \mathrm{KCl}$ ). His $_{6}$-eIF4AI was dialyzed against $20 \mathrm{mM}$ Tris $_{7.5}, 0.1 \mathrm{mM}$ EDTA, and 10\% glycerol, while $\mathrm{His}_{6}$-eIF4H was dialyzed against $20 \mathrm{mM} \mathrm{HEPES}_{7.5}, 50 \mathrm{mM} \mathrm{KCl}, 0.1 \mathrm{mM}$ EDTA, and $25 \%$ glycerol. eIF4AI-GST was purified as previously described (Bordeleau et al. 2006a).

\section{Generation of mRNA substrates}

For chemical cross-linking reactions, CAT RNA was transcribed from pSP/CAT linearized with PvuII using SP6 RNA polymerase. The RNA was cap-labeled with guanylyltransferase and $\alpha-{ }^{32} \mathrm{P}-$ GTP, followed by oxidation with $\mathrm{NaIO}_{4}$ (Sonenberg 1981). For $\mathrm{UV}_{254}$-induced cross-linking, non-oxidized ${ }^{32} \mathrm{P}$-cap-labeled CAT mRNA was used. For $\mathrm{UV}_{365}$-induced cross-linking, RNA with a $4 \mathrm{SU}$ residue $2 \mathrm{nt}$ downstream $\left(4 \mathrm{SU}^{2}\right)$ from the cap structure was generated by in vitro transcription from the following annealed oligos: 5' -CTGCTTGTCCGTTGTTGACCCTATAGTGAGTCGTA TTA-3' and 5'-TAATACGACTCACTATAG-3', using T7 RNA polymerase (New England Biolabs) in the presence of 4-thio-UTP (Ambion) and omitting UTP from the transcription reaction. Following extraction with phenol/chloroform, G50 spin column purification, and ethanol precipitation, the RNA was cap-labeled with guanylyltransferase and $\alpha-{ }^{32}$ P-GTP (Pelletier and Sonenberg 1985b).

RNAs with a single $4 S U 12,22$, or 52 nt downstream from the cap structure $\left(4 \mathrm{SU}^{12}, 4 \mathrm{SU}^{22}, 4 \mathrm{SU}^{52}\right)$ were created by ligation of an acceptor RNA to a donor RNA (Moore and Query 1998). The acceptor RNAs, which determine the distance of the 4-thiouridine from the cap, were in vitro transcribed in the presence of cap analog (NEB) from oligonucleotides:

4SU ${ }^{12}$ RNA: 5' -CTGCTTGTCCCTATAGTGAGTCGTATTA-3', 4SU ${ }^{22}$ RNA: $5^{\prime}$-CTGCTTGTCCTGTTGTTGCCCTATAGTGAGT CGTATTA- ${ }^{\prime}$, and

4SU ${ }^{52}$ RNA: 5'-CTGCTTGTCCTGTTGTTGCCTGTTGTTGCCT GTTGTTGCCTCTTGTTGCCCTATAGTGAGTCGTATTA-3',

hybridized to the $\mathrm{T} 7$ promoter primer ( $5^{\prime}$-TAATACGACTCACTA TAG-3'), and using T7 RNA polymerase (NEB). The donor RNA (5'-G[4SU]GACUGACACAUGAGACAAG-3') (Dharmacon) was kinased with $\gamma^{32} \mathrm{P}$-ATP (Perkin Elmer: $6000 \mathrm{Ci} / \mathrm{mmol}$ ), hybridized to a DNA splint that was complementary to the donor and acceptor RNA, followed by ligation using T4 DNA ligase (NEB). Hybridizations were performed using $4 \mu \mathrm{M}$ of donor, acceptor, and splint in T4 DNA ligase buffer (NEB) by heating to $95^{\circ} \mathrm{C}$ in a heat block and slowly cooling to $4^{\circ} \mathrm{C}$. Following ligations, the splint was digested with DNAse I (Ambion) and the RNA was fractionated onto an $8 \mathrm{M}$ urea/10\% polyacrylamide gel, visualized by autoradiography, excised, and eluted from the gel slice with $5 \mathrm{~mL} 0.5 \mathrm{M}$ $\mathrm{NH}_{4} \mathrm{OAc} / 1 \mathrm{mM}$ EDTA overnight at $4^{\circ} \mathrm{C}$. The RNA was purified by diluting the elution threefold, loading onto a DE52 column, followed by washing with $1 \mathrm{~mL}$ of buffer $\left(50 \mathrm{mM} \mathrm{Tris}_{7.5}, 50 \mathrm{mM}\right.$ $\mathrm{NH}_{4} \mathrm{OAc}, 1 \mathrm{mM}$ EDTA) and eluting with elution buffer (50 mM Tris $_{7.5}, 0.5 \mathrm{M} \mathrm{NH}_{4} \mathrm{OAc}, 1 \mathrm{mM}$ EDTA, 50\% deionized formamide). Elutions were ethanol-precipitated using glycogen as carrier, resuspended in water, and quantitated by Cherenkov counting.

\section{Cross-linking assays}

Chemical cross-linking reactions were performed as previously described (Sonenberg 1981). Briefly, a $25-\mu \mathrm{L}$ reaction containing
$10 \mu \mathrm{L}$ RSW $(1.2 \mu \mathrm{g} / \mu \mathrm{L})$ was incubated under standard conditions (25 $\mathrm{mM} \mathrm{HEPES}_{7.5}, 70 \mu \mathrm{M}$ GTP, $9 \mathrm{mM}$ creatine phosphate, $11 \mu \mathrm{M}$ of each of the amino acids, $2 \mathrm{mM}$ DTT, $0.2 \mathrm{mM}$ spermidine, $60 \mu \mathrm{M}$ PMSF, and $0.5 \mathrm{mM} \mathrm{Mg}[\mathrm{OAc}]_{2}$ ) with $0.9 \mathrm{mM}$ ATP (unless indicated otherwise) in the presence of oxidized ${ }^{32} \mathrm{P}$-labeled CAT RNA $(50,000 \mathrm{cpm})$. Reactions were incubated for $10 \mathrm{~min}$ at $30^{\circ} \mathrm{C}$ and then cross-linked using $20 \mathrm{mM} \mathrm{NaBH}_{3} \mathrm{CN}$ overnight at $4^{\circ} \mathrm{C}$. After treatment with RNAse A, proteins were separated by $10 \%$ SDS-PAGE and visualized by autoradiography (Kodak X-Omat). The addition of either $0.6 \mathrm{mM} \mathrm{m}^{7} \mathrm{GDP}$ or $0.6 \mathrm{mM}$ GDP to crosslinking reactions was used to determine cap specificity.

Photochemical cross-linking reactions at $\mathrm{UV}_{254}$ with non-oxidized mRNA were performed essentially as previously described (Pelletier and Sonenberg 1985b). Using the same conditions as the chemical cross-linking assay, reactions were incubated for $10 \mathrm{~min}$ at $30^{\circ} \mathrm{C}$ with ${ }^{32} \mathrm{P}$-cap-labeled CAT RNA $(50,000 \mathrm{cpm})$ and crosslinked with a UVP Multiple-Ray Lamp (Fisher) using the shortwave germicidal lamp $(254 \mathrm{~nm})$ placed $\sim 4 \mathrm{~cm}$ above the sample on ice for $20 \mathrm{~min}$. After treatment with RNAse A, proteins were separated by $10 \%$ SDS-PAGE and visualized by autoradiography.

$\mathrm{UV}$-induced cross-linking at $\mathrm{UV}_{365}$ was performed as described for the $\mathrm{UV}_{254}$-induced cross-linking assay, except cross-linking as performed with a Rad-Free Long Wave UV lamp (365 nm) (Schleicher \& Schuell) and RNA with a single incorporated 4-thiouridine was used (20,000-100,000 cpm).

\section{Antibodies, Western blotting, and immunoprecipitations}

The anti-eIF4B antibody has been previously described (Methot et al. 1996). Anti-eIF4H antibodies were raised in rabbits against murine recombinant protein. Anti-eIF4E and anti-eIF4GI (directed to the carboxy-terminal domain of eIF4GI) were a kind gift of Dr. Nahum Sonenberg (McGill University). The rabbit polyclonal anti-eIF3a, -eIF3c, -eIF3d, and -eIF3g antibodies were previously described (Masutani et al. 2007). Western blots were performed using Immobilon-P (Millipore) membranes probed with the indicated antibodies and visualized by chemiluminescence using an ECL kit (Amersham).

For IPs, cross-linking reactions were treated with RNAse A and diluted with IP buffer (see below), at which point antibody was added, followed by incubation end over end at $4^{\circ} \mathrm{C}$ overnight. Prewashed protein-A beads or protein-G beads (for eIF4E) (Amersham) were added and incubated for 3-4 h end over end at $4^{\circ} \mathrm{C}$. After extensive washing with the IP buffer, samples were boiled in Laemmli sample buffer and separated on a $10 \%$ SDSpolyacrylamide gel, which was dried and exposed at $-70^{\circ} \mathrm{C}$ with $\mathrm{X}$-Omat (Kodak) film. IPs with $\alpha$-eIF4E, $\alpha$-eIF4H, $\alpha$-eIF3a, and $\alpha$-eIF3c were performed under mild conditions (20 mM HEPES $_{7.5}$, $100 \mathrm{mM} \mathrm{KCl}, 10 \%$ glycerol, $1 \mathrm{mM}$ EDTA, $0.1 \%$ NP-40), whereas $\alpha$-eIF4GI, $\alpha$-eIF4B, $\alpha$-eIF3d, and $\alpha$-eIF3g were used in a modified RIPA buffer (10 mM Tris $7.5,600 \mathrm{mM} \mathrm{KCl}, 150 \mathrm{mM} \mathrm{NaCl}, 5 \mathrm{mM}$ EDTA, 2\% Triton X-100).

\section{ACKNOWLEDGMENTS}

L.L. was supported by a CIHR Chemical Biology and an NSERC CGSM fellowship. This work was supported by a grant from CIHR (MOP-11354) to J.P.

Received December 21, 2007; accepted February 15, 2008. 


\section{REFERENCES}

Asano, K., Merrick, W.C., and Hershey, J.W. 1997. The translation initiation factor eIF3-p48 subunit is encoded by int-6, a site of frequent integration by the mouse mammary tumor virus genome. J. Biol. Chem. 272: 23477-23480.

Block, K.L., Vornlocher, H.P., and Hershey, J.W. 1998. Characterization of cDNAs encoding the p44 and p35 subunits of human translation initiation factor eIF3. J. Biol. Chem. 273: 3190131908.

Bordeleau, M.E., Cencic, R., Lindqvist, L., Oberer, M., Northcote, P., Wagner, G., and Pelletier, J. 2006a. RNA-mediated sequestration of the RNA helicase eIF4A by Pateamine A inhibits translation initiation. Chem. Biol. 13: 1287-1295.

Bordeleau, M.-E., Mori, A., Oberer, M., Lindqvist, L., Chard, L.S., Higa, T., Belsham, G.J., Wagner, G., Tanaka, J., and Pelletier, J. 2006b. Functional characterization of IRESes by an inhibitor of the RNA helicase eIF4A. Nat. Chem. Biol. 2: 213-220.

Browning, K.S., Gallie, D.R., Hershey, J.W., Hinnebusch, A.G., Maitra, U., Merrick, W.C., and Norbury, C. 2001. Unified nomenclature for the subunits of eukaryotic initiation factor 3. Trends Biochem. Sci. 26: 284.

Buratti, E., Tisminetzky, S., Zotti, M., and Baralle, F.E. 1998. Functional analysis of the interaction between HCV 5' UTR and putative subunits of eukaryotic translation initiation factor eIF3. Nucleic Acids Res. 26: 3179-3187.

Cristofari, G. and Darlix, J.L. 2002. The ubiquitous nature of RNA chaperone proteins. Prog. Nucleic Acid Res. Mol. Biol. 72: 223-268.

Dmitriev, S.E., Terenin, I.M., Dunaevsky, Y.E., Merrick, W.C., and Shatsky, I.N. 2003. Assembly of 48 S translation initiation complexes from purified components with mRNAs that have some base pairing within their $5^{\prime}$ untranslated regions. Mol. Cell. Biol. 23: $8925-8933$.

Duncan, R., Milburn, S.C., and Hershey, J.W. 1987. Regulated phosphorylation and low abundance of HeLa cell initiation factor eIF-4F suggest a role in translational control. Heat shock effects on eIF-4F. J. Biol. Chem. 262: 380-388.

Edery, I. and Sonenberg, N. 1985. Cap-dependent RNA splicing in a HeLa nuclear extract. Proc. Natl. Acad. Sci. 82: 7590-7594.

Gradi, A., Imataka, H., Svitkin, Y.V., Rom, E., Raught, B., Morino, S., and Sonenberg, N. 1998. A novel functional human eukaryotic translation initiation factor 4G. Mol. Cell. Biol. 18: 334-342.

Holz, M.K., Ballif, B.A., Gygi, S.P., and Blenis, J. 2005. mTOR and S6K1 mediate assembly of the translation preinitiation complex through dynamic protein interchange and ordered phosphorylation events. Cell 123: 569-580.

Imataka, H. and Sonenberg, N. 1997. Human eukaryotic translation initiation factor $4 \mathrm{G}$ (eIF4G) possesses two separate and independent binding sites for eIF4A. Mol. Cell. Biol. 17: 6940-6947.

Kapp, L.D. and Lorsch, J.R. 2004. The molecular mechanics of eukaryotic translation. Annu. Rev. Biochem. 73: 657-704.

Kolupaeva, V.G., Pestova, T.V., Hellen, C.U., and Shatsky, I.N. 1998. Translation eukaryotic initiation factor $4 \mathrm{G}$ recognizes a specific structural element within the internal ribosome entry site of encephalomyocarditis virus RNA. J. Biol. Chem. 273: 1859918604.

Konarska, M.M., Padgett, R.A., and Sharp, P.A. 1984. Recognition of cap structure in splicing in vitro of mRNA precursors. Cell 38: 731-736.

Lawson, T.G., Cladaras, M.H., Ray, B.K., Lee, K.A., Abramson, R.D., Merrick, W.C., and Thach, R.E. 1988. Discriminatory interaction of purified eukaryotic initiation factors $4 \mathrm{~F}$ plus $4 \mathrm{~A}$ with the $5^{\prime}$ ends of reovirus messenger RNAs. J. Biol. Chem. 263: 7266-7276.

LeFebvre, A.K., Korneeva, N.L., Trutschl, M., Cvek, U., Duzan, R.D., Bradley, C.A., Hershey, J.W., and Rhoads, R.E. 2006. Translation initiation factor eIF4G-1 binds to eIF3 through the eIF3e subunit. J. Biol. Chem. 281: 22917-22932.

Lopez de Quinto, S., Lafuente, E., and Martinez-Salas, E. 2001. IRES interaction with translation initiation factors: Functional charac- terization of novel RNA contacts with eIF3, eIF4B, and eIF4GII. RNA 7: 1213-1226.

Lorsch, J.R. and Herschlag, D. 1999. Kinetic dissection of fundamental processes of eukaryotic translation initiation in vitro. $E M B O J .18$ : 6705-6717.

Masutani, M., Sonenberg, N., Yokoyama, S., and Imataka, H. 2007. Reconstitution reveals the functional core of mammalian eIF3. EMBO J. 26: 3373-3383.

Methot, N., Song, M.S., and Sonenberg, N. 1996. A region rich in aspartic acid, arginine, tyrosine, and glycine (DRYG) mediates eukaryotic initiation factor 4B (eIF4B) self-association and interaction with eIF3. Mol. Cell. Biol. 16: 5328-5334.

Moore, M.J. and Query, C.C. 1998. Uses of site-specifically modified RNAs constructed by RNA ligation. In RNA: protein interactions. A practical approach (ed. C.W.J. Smith), pp. 75-108. Oxford University Press, Oxford, UK.

Nygård, O. and Westermann, P. 1982. Specific interaction of one subunit of eukaryotic initiation factor eIF-3 with $18 \mathrm{~S}$ ribosomal RNA within the binary complex, eIF-3 small ribosomal subunit, as shown by cross-linking experiments. Nucleic Acids Res. 10: 13271334. doi: 10.1093/nar/10.4.1327.

Oberer, M., Marintchev, A., and Wagner, G. 2005. Structural basis for the enhancement of eIF4A helicase activity by eIF4G. Genes \& Dev. 19: 2212-2223.

Parkin, N.T., Cohen, E.A., Darveau, A., Rosen, C., Haseltine, W., and Sonenberg, N. 1988. Mutational analysis of the 5 ' non-coding region of human immunodeficiency virus type 1: Effects of secondary structure on translation. EMBO J. 7: 2831-2837.

Pause, A., Methot, N., Svitkin, Y., Merrick, W.C., and Sonenberg, N. 1994. Dominant negative mutants of mammalian translation initiation factor eIF-4A define a critical role for eIF-4F in capdependent and cap-independent initiation of translation. EMBO J. 13: $1205-1215$.

Pelletier, J. and Sonenberg, N. 1985a. Insertion mutagenesis to increase secondary structure within the $5^{\prime}$ noncoding region of a eukaryotic mRNA reduces translational efficiency. Cell 40: 515526.

Pelletier, J. and Sonenberg, N. 1985b. Photochemical cross-linking of cap binding proteins to eucaryotic mRNAs: Effect of mRNA $5^{\prime}$ secondary structure. Mol. Cell. Biol. 5: 3222-3230.

Pestova, T.V., Shatsky, I.N., and Hellen, C.U. 1996. Functional dissection of eukaryotic initiation factor $4 \mathrm{~F}$ : The $4 \mathrm{~A}$ subunit and the central domain of the $4 \mathrm{G}$ subunit are sufficient to mediate internal entry of $43 \mathrm{~S}$ preinitiation complexes. Mol. Cell. Biol. 16: $6870-6878$

Pestova, T.V., Kolupaeva, V.G., Lomakin, I.B., Pilipenko, E.V., Shatsky, I.N., Agol, V.I., and Hellen, C.U. 2001. Molecular mechanisms of translation initiation in eukaryotes. Proc. Natl. Acad. Sci. 98: 7029-7036.

Pestova, T.V., Lorsch, J.R., and Hellen, C.U.T 2007. The mechanism of translation initiation in eukaryotes. Cold Spring Harbor Laboratory Press, Cold Spring Harbor, NY.

Pilipenko, E.V., Pestova, T.V., Kolupaeva, V.G., Khitrina, E.V., Poperechnaya, A.N., Agol, V.I., and Hellen, C.U. 2000. A cell cycle-dependent protein serves as a template-specific translation initiation factor. Genes \& Dev. 14: 2028-2045.

Rogers Jr., G.W., Richter, N.J., Lima, W.F., and Merrick, W.C. 2001. Modulation of the helicase activity of eIF4A by eIF4B, eIF4H, and eIF4F. J. Biol. Chem. 276: 30914-30922.

Shahbazian, D., Roux, P.P., Mieulet, V., Cohen, M.S., Raught, B., Taunton, J., Hershey, J.W., Blenis, J., Pende, M., and Sonenberg, N. 2006. The mTOR/PI3K and MAPK pathways converge on eIF4B to control its phosphorylation and activity. EMBO J. 25: 2781-2791.

Siridechadilok, B., Fraser, C.S., Hall, R.J., Doudna, J.A., and Nogales, E. 2005. Structural roles for human translation factor eIF3 in initiation of protein synthesis. Science 310: 1513-1515.

Sizova, D.V., Kolupaeva, V.G., Pestova, T.V., Shatsky, I.N., and Hellen, C.U. 1998. Specific interaction of eukaryotic translation 
initiation factor 3 with the $5^{\prime}$ nontranslated regions of hepatitis C virus and classical swine fever virus RNAs. J. Virol. 72: 47754782 .

Sonenberg, N. 1981. ATP $/ \mathrm{Mg}^{++}$-dependent cross-linking of cap binding proteins to the $5^{\prime}$ end of eukaryotic mRNA. Nucleic Acids Res. 9: 1643-1656. doi: 10.1093/nar/9.7.1643.

Sonenberg, N. 1988. Cap-binding proteins of eukaryotic messenger RNA: Functions in initiation and control of translation. Prog. Nucleic Acid Res. Mol. Biol. 35: 173-207.

Sonenberg, N., Morgan, M.A., Merrick, W.C., and Shatkin, A.J. 1978. A polypeptide in eukaryotic initiation factors that crosslinks specifically to the $5^{\prime}$-terminal cap in mRNA. Proc. Natl. Acad. Sci. 75: 4843-4847.

Svitkin, Y.V., Pause, A., Haghighat, A., Pyronnet, S., Witherell, G., Belsham, G.J., and Sonenberg, N. 2001. The requirement for eukaryotic initiation factor $4 \mathrm{~A}(\mathrm{elF} 4 \mathrm{~A})$ in translation is in direct proportion to the degree of mRNA $5^{\prime}$ secondary structure. RNA 7: 382-394.

Vornlocher, H.P., Hanachi, P., Ribeiro, S., and Hershey, J.W. 1999. A 110-kilodalton subunit of translation initiation factor eIF3 and an associated 135-kilodalton protein are encoded by the Saccharomyces cerevisiae TIF32 and TIF31 genes. J. Biol. Chem. 274: 1680216812. 

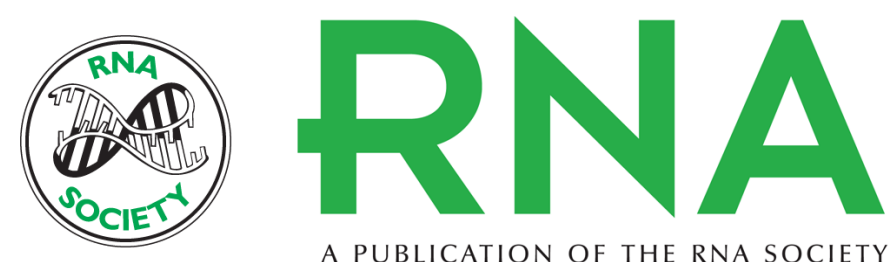

A PUBLICATION OF THE RNA SOCIETY

\section{Cap-dependent eukaryotic initiation factor-mRNA interactions probed by cross-linking}

Lisa Lindqvist, Hiroaki Imataka and Jerry Pelletier

RNA 2008 14: 960-969

References This article cites 40 articles, 22 of which can be accessed free at:

http://rnajournal.cshlp.org/content/14/5/960.full.html\#ref-list-1

\section{License}

Email Alerting Receive free email alerts when new articles cite this article - sign up in the box at the Service top right corner of the article or click here. 